\title{
MATRix Regimen
}

National Cancer Institute

\section{Source}

National Cancer Institute. MATRix Regimen. NCI Thesaurus. Code C140106.

A regimen consisting of high-dose methotrexate, high-dose cytarabine, thiotepa and rituximab that can be used in the treatment of central nervous system (CNS) lymphoma and as a conditioning regimen for autologous stem cell transplantation (ASCT). 